\title{
Geological Behaviours in Urban Areas for Surface Runoff and Recharge
}

\author{
Sheetal Sharma \\ Department of Architecture \& Planning, Maulana Azad National Institute of Technology (MANIT), Bhopal, India \\ Email: sheetalsharmaplanner@gmail.com
}

How to cite this paper: Sharma, S. (2017) Geological Behaviours in Urban Areas for Surface Runoff and Recharge. Open Journal of Soil Science, 7, 181-201.

https://doi.org/10.4236/ojss.2017.78014

Received: June 6, 2017

Accepted: August 26, 2017

Published: August 29, 2017

Copyright (C) 2017 by author and Scientific Research Publishing Inc. This work is licensed under the Creative Commons Attribution-NonCommercial International License (CC BY-NC 4.0). http://creativecommons.org/licenses/by-nc/4.0/ (c) (i) (8) Open Access

\begin{abstract}
Urbanization is rapidly growing all over the world affecting life styles and environment to a large scale. The most challenging impacts that can be observed are the reducing water levels and increasing surface flows in form of flash floods. Urban sprawl has converted hectares of agriculture and forest land into developed surfaces which have zero infiltration resulting in increased flow of precipitation. Apart from sealed land surfaces, the ignorance of soil behavior also leads to added surface flows and unnatural infiltration into soil. Incompatibility of urban planning and functions with the natural environment is becoming vast. Changes in land patterns due to Build up, pavements, roads and similar land cover affect surface water flow seriously. Wise use of modern means and best technologies available are not in use resulting in a huge gap between basic knowledge of natural processes and its requirement for balanced development having minimum impact on water recharge. Present paper is a research on various soil groups and urban water sheds for impacts of increasing Build up on runoff and behavior of soil under developed conditions. The method adopted was to analyze Build up from 1971 to 2014 using ArcGis 9.3 and hydrological modeling using SWMM software for resulting runoff in 40 years of urbanization. Results were compared for different soil groups to observe best conditions for suitable Build up on soil groups for sustainable development.
\end{abstract}

\section{Keywords}

Component, Formatting, Style, Styling, Insert

\section{Introduction}

Natural systems are already responding increasingly making their presence by extreme weather events in the recent decades like floods, droughts, tsunamis, 
earthquakes along with world's rivers, lakes, wildlife, glaciers, permafrost, coastal zones, disease carriers and many other elements of the natural and physical environment leading to imbalance and natural hazards. Many activities like UNESCO, UNEP, IPCC and UNHSP at international level during last decade have been developing a basis for the rational use and conservation of the resources of biosphere, to overcome the impacts of climate change for the improvement of the relationship between man and environment within the natural and social [1]. The assessment reports of IPCC 2007 and 2013 have stated that warming of the climate system is unequivocal, and since the 1950s, many of the observed changes are unprecedented over decades to millennia. The atmosphere and ocean have warmed, the amounts of snow and ice have diminished, sea level has risen, and the concentrations of greenhouse gases have increased. Gradually each decade is getting warmer from the previous one. Confidence in precipitation change averaged over global land areas since 1901 is low prior to 1951 and medium afterwards [2] [3].

The most notable changes observed are related to the urban and hydrological system where urban areas have increased from 100,000 to 5,000,000 and as per United Nation's projections, half of the urban population would live in urban areas with $85.9 \%$ around in 2050 for developing and developed countries. Build up associated with urban areas have also had noticeable change of $145.68 \%$ as compared to 54.05\% change in Population Growth from 1971 to 1999. Also UN report of 2013 stated that the urban population will increase from 29.1 in 1950 to 66.6 in 2050. As per the State of resource, UNESCO [4] reported that water is predicted to be the primary medium through which early climate change impacts will be felt by people, ecosystems and economies [5]. Hydrology has suffered drastic changes in its components felt changes in recharge that dropped from $45 \%$ $50 \%$ in 1961 to $-10 \%$ to $-30 \%$ in 2050 as per the UNEP and IGRAC.

Many changes in hydrological cycle are both positive and negative in different aspects of urban and water systems. Increased annual runoff may produce benefits for a variety of both in stream and out-of-stream water users by increasing renewable water resources, but may simultaneously generate harm by increasing flood risk [6]. Water scarcity on the other hand is already becoming a burning issue in most of the cities and countries. Precipitation pattern is also showing a temporal variation in its behavior in many of the urban and rural areas [7]. Second, Rising temperatures are accelerating the hydrological cycle and causing rivers and lakes to freeze later in the autumn. Predictions are already being made for irregular, variant and extreme possibilities of weather events. IPCC 2007 Human activities and urbanization is likely to affect climate change which in result will impose extreme weather events [1] [8].

Both observational records and climate projections provide strong evidence that freshwater resources are vulnerable, and have the potential to be strongly impacted by the increasing urban areas. The variations in climate change are having impacts on many natural cycles like extreme precipitation-related weath- 
er and climate events, observations and reports indicate areas with heavy precipitation increasing intensities, increase in areas affected by droughts, and intense tropical cyclone increase, damaging to crops, soil erosion, land degradation, lower yields, damage to ability of land to cultivate. More intense rainfall events will increase runoff percentages and will overload the capacity of sewer systems and water and wastewater treatment plants more often. One reason is that precipitation variability is very likely to increase, and more frequent floods and droughts are anticipated.

Thus changes in land use and land cover due to urbanization are likely to impact water requirement as some places leading to water scarcity and some with flash floods. Dynamic land use changes and soil transitions bring challenges not only for Social, hydrological, geological and urban Systems but also for over all ecological systems and decision making processes creating an urgent need for planning and developing parallel solutions to changing world.

\section{Literature Review}

\subsection{Relation between Soil, Urban and Hydrological System}

As per the US Drought Mitigation Centre "The processes of evaporation and transpiration (evapotranspiration) are closely linked to the water found in soil moisture; these processes act as driving forces on water transferred in the hydrological cycle [9] that are difficult to measure and require demanding analyses in order to calculate an acceptable level of accuracy. Evaporation from surface water bodies such as lakes, rivers, wetlands and reservoirs is also an important component of the hydrological cycle and integral to basin development and regional water management" [10].

The soil moisture contents in any area mark the availability of underground water as well as influence up to great extent the occurrence of precipitation and its nature. The water bodies also define the water level in the soil column. Hence it essential for planners to have knowledge for the soil below and water availability before development as future implications of climate and hydrological information can be predicted and water future can be forecasted. Also this will be helpful to maintain the water table during development. But urban planning is still not using this parameter as a tool for land use-land cover planning though many square kilometer of land and soil moisture gets directly affected by the urban development.

\subsubsection{Effects of Impervious Area to Water Recharge and Drainage Flow}

1) Impervious surface area:

Impervious surfaces associated with urbanization include roads, sidewalks, parking lots, and buildings-any artificial, hardened surface that reduces permeability and infiltration of water into the soil.

2) Water holding capacity of soils:

Behavior of soil is related to its own properties and hence to correlate it with urban and hydrology, some basic qualities of different soils related to water were 
studied. Table 1 indicates the water holding capacity for soils.

\subsubsection{Observations of Hydrological Changes as per Case Studies}

The management of surface water flooding is hindered by the characteristics of urban Drainage. The presence of impervious non porous surfaces in urban area (such as Buildings Roads, car parks) raises the volume of surface water runoff, lowers the underground water percolation from paved coverings [12].

Urbanization is the process of converting natural soil to a sealed one with almost non porous open spaces that are responsible for holding and transfer of water to the soil beneath. Restraining this natural cycle increases the runoff factor in such sealed spaces and hence imbalancing the natural phenomenon of infiltration, evaporation, runoff and evapotranspiration.

Many research have been done for modeled surface water runoff as sown in Table 2, from different types of land uses and found that runoff increases with

Table 1. Water holding capacity for different soils.

\begin{tabular}{ccc}
\hline Soil & Soil type & $\begin{array}{c}\text { Water holding capacity } \\
\text { (when pressure not applied) }\end{array}$ \\
\hline Alluvial & Clay & $70 \%-80 \%$ \\
Sandstone & Loamy & $80 \%-90 \%$ \\
Sandstone & Loamy sand & $30 \%-40 \%$ \\
Basalt & Silt loam & $70 \%-75 \%$ \\
Basalt & Silty clay loam & $70 \%-80 \%$ \\
\hline
\end{tabular}

Source: (Agvise Laboratories, 2001) [11].

Table 2. Reading and observations for variations in infiltration runoff and evapotranspiration from case studies.

\begin{tabular}{|c|c|c|c|c|}
\hline Case studies & $\%$ vegetated & $\%$ infiltration & $\%$ runoff & Evapo-transpiration \\
\hline Natural condition & natural & 50 & 10 & 10 \\
\hline Modified & modified & 6 & 50 & \\
\hline \multirow[t]{2}{*}{ Northwest England } & 66 & 1 & 32 & 1 \\
\hline & 20 & 4 & 74 & 2 \\
\hline \multirow[t]{4}{*}{$\begin{array}{l}\text { California, } \\
\text { Thompson creek }\end{array}$} & natural & $\begin{array}{c}50(25 \text { shallow }+25 \\
\text { deep })\end{array}$ & 10 & 40 \\
\hline & $80-90$ & $42(21+21)$ & 20 & 38 \\
\hline & $50-65$ & $35(20+15)$ & 30 & 35 \\
\hline & $0-50$ & $15(10+5)$ & 55 & 30 \\
\hline \multirow[t]{2}{*}{ Harzliya, Israel } & $30-40$ (residential & & 45 & \\
\hline & $60-75$ (industrial) & & 90 & \\
\hline $\begin{array}{c}\text { Vegetated cover in low } \\
\text { density areas }\end{array}$ & 66 & & 32 & \\
\hline $\begin{array}{c}\text { Very less vegetated town } \\
\text { centre's }\end{array}$ & 20 & & 74 & \\
\hline
\end{tabular}


proportion of Build up areas [12].

\subsubsection{Western Scenario}

Therefore it is apparent from Table 1 that land use, land cover and the evapotranspiring surfaces have a significant influence on behavior of water in urban water cycle and related urban flooding. Similarly Induction of Build up areas around natural water routes make these readings more focused on placement of Land use-land cover as per accordance to the natural landscaping behavior.

\subsubsection{Indian Scenario}

Study of some Indian Major Urban Centre's for variations in Components of Hydrological Cycle and land cover depicting to impervious areas reveal that Build up areas and water withdrawal has resulted in declining of water levels in areas [12] as shown in Figure 1.

The Indian Urban centers (Figure 1) as ranked worldwide as per their urbanization extent and as per their Urban land area (footprints) were observed in reference of the specific water supply and demand for these urban cities and also the density and source of available water resources are compared to achieve a correlation of urban centers and availability of water or shortage of water. Urban centers like Delhi, Nagpur, Bhopal, Jaipur are having severe shortage of water supply and water is being transported from various sources, $25 \mathrm{~km} \cdot \mathrm{s}$ away from cities. Among these many cities have water availability potential which is deteriorating at fast rate. Instant urbanization is considered as the cause for difference in supply and demand.

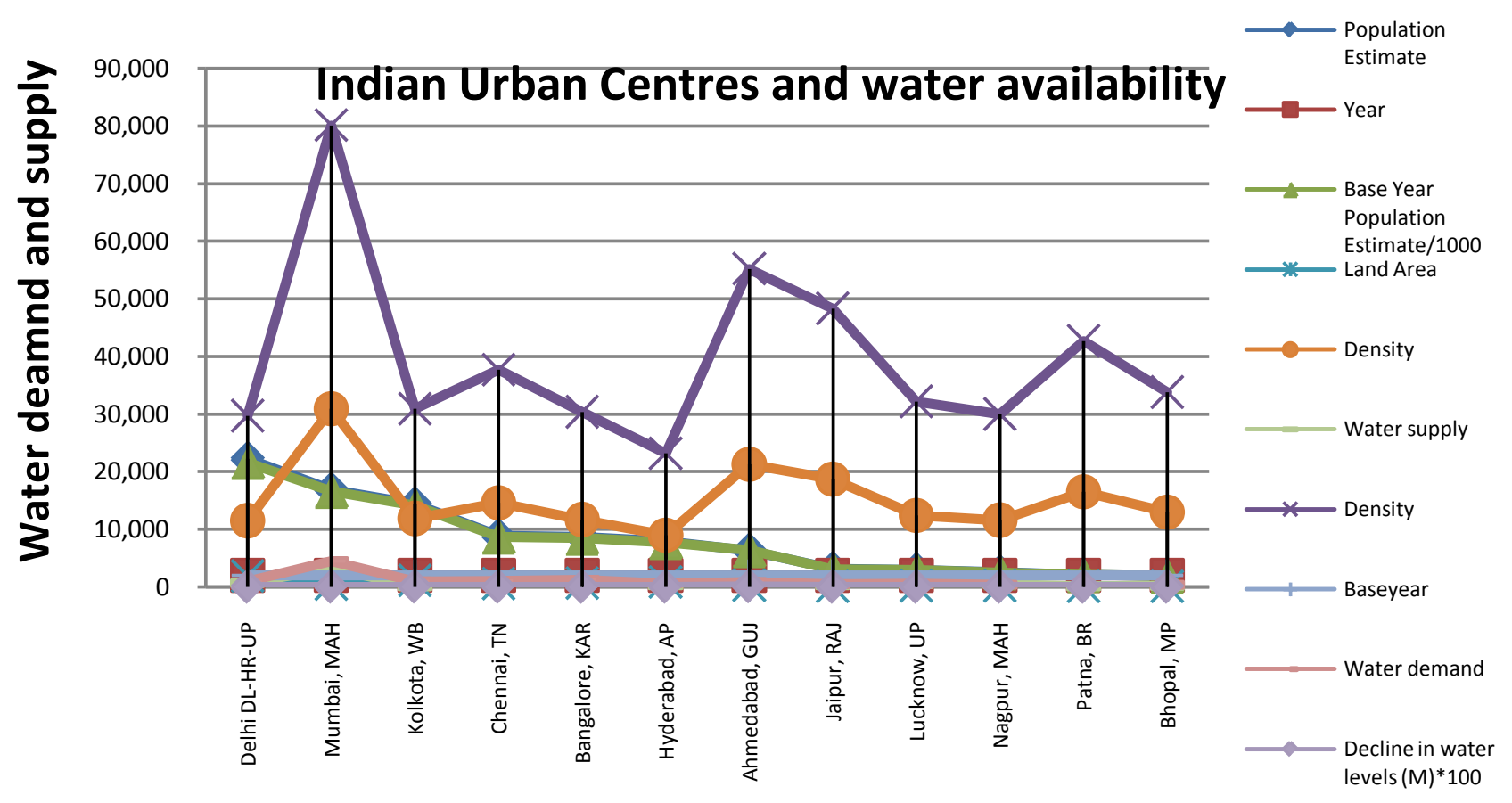

\section{CITIES}

Figure 1. Indian urban centers with population, land area and water availability [13]. 


\section{Need}

Urbanization is a major issue in now a day's scenario and water scarcity and flash floods too are directly linked with urban areas correlating the increasing Build up areas.

However constant increase in urban areas is lacking and ignoring the effects of urbanization and thus hampering the working natural courses of environmental systems like water cycle and continuously harming the environment as well through on surface and sub surface water variations. Though efforts have been constant for creating balance between two, still urbanization being at its fast pace is keeping thoughts and actions behind. Thus spatial planning needs a fast, improved and scientific as well as technical thought for planning and implementation of these balancing ideas in accordance with due consideration to maintaining natural regime along with development.

To maintain balance between ever dynamic population increase and decrease of underground water availability, the gap between increases in population resulting more Build up areas and rate of water availability has to be reduced.

Urban planners have to be updated with natural cycle and modern means as well as best technologies for maintaining the balance between urban system and natural system, but there is a huge gap between basic main streaming of knowledge of natural processes with physical planning studies and its requirement for balanced development.

\section{Methodology}

Figure 2 depicts the broad methodology adopted to observe the correlations between soil, development and water. The study was carried out by observing individual systems first and then their interactions with other systems with most affecting variables. Urbanization, soil properties and water moisture content with water table variations were most observed parameters for a span of 40 years to get correlations among systems.

\section{Simulation}

The two methods for simulation used were:

1) By keeping precipitation and slope, width constant for respective years and;

2) By changing precipitation on hourly and daily basis to observe long term run off changes and short term peak flow changes.

Model results obtained were tested for accuracy by regression model and the difference between observed and simulated Hydrographs were checked for least error.

The runoff changes for constant precipitation with changing Build up were analyzed first. The combinations of inter location runoff and the intra location runoff were used to form the Correlation Equation and the constants $\left(\mathrm{y}=\mathrm{Ax}^{2}+\right.$ $\mathrm{bx}+\mathrm{c}$ ) where $\mathrm{y}$ is runoff and $\mathrm{x}$ is Build up.

The correlation observations for each catchment for each decade was plotted 


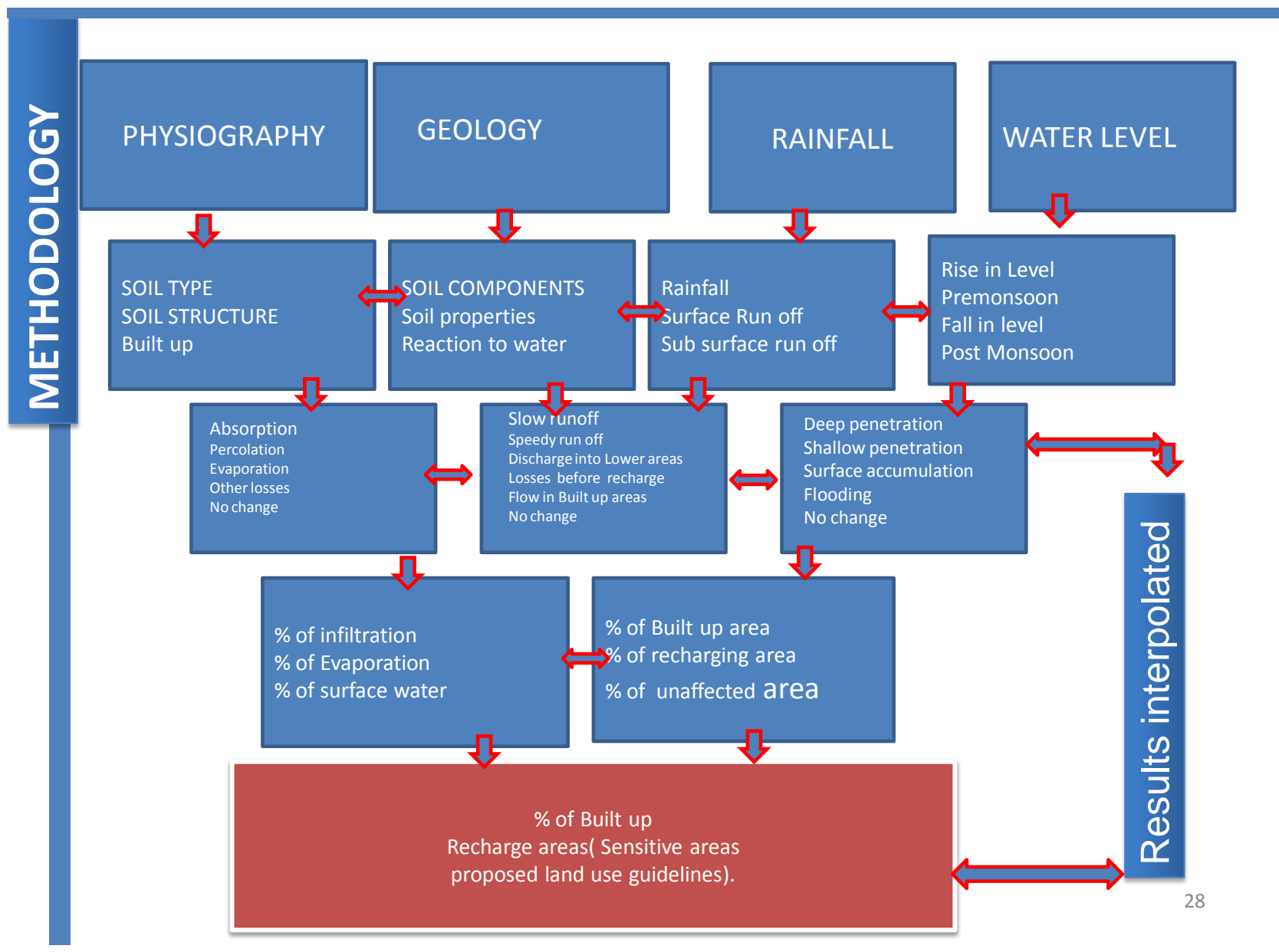

Figure 2. Methodology for hydrological modeling.

to see the trend line and the resulting equation. To calibrate the hydrologic model the LULC data was prepared in an $8 \mathrm{~m}$ grid. The time series data was made for hourly rainfall event.

Finally, the simulation was run for different years as per conditions prevailing for that specified times and the continuity errors as well as flow routing errors were minimized to get accurate results. The obtained report of the rainfall runoff was then observed and compared for viewing results and changes in the parameters. The correlation analysis was performed to obtain a correlation and best fit method was used to get minimum error value.

The correlation thus formed was observed for various catchments individually, i.e., inter location and then with others with same characteristics over all the study area, i.e., intra location.

The simulation was run with following time series:

1) Critical rainfall runoff analysis from June to September;

2) Critical rainfall runoff analysis for peak hour (24 hours);

3) Rainfall-Runoff analysis with varying precipitation;

4) Rainfall-Runoff analysis for Build up as per rule and Build up as per actual. 


\section{Study Area-Bhopal (India)}

The study area selected covers two Urban Areas constituting several wards of Bhopal District, State Madhya Pradesh, and Country India (Figure 3). The areas selected have two different urban Catchment forms. One with developing character with specific geological setup and other with developed character and different geological set-up. Both areas have recently being facing water level drop; one has a recharge zone character and other have discharge zone character. The wards coming within these natural boundaries have been taken for observation and analysis. It consists of Area Colony, Shahpura, ChunaBhatti and Manit. The study area comprises of Natural Drainage of Kaliasot River along with Kaliasot Dam, Bhadbhada area (Soil way of Upper lake), Southern Portion of Upper Lake, Hills like Samasgarh, Forest Areas near Chichli, Nayagoan, The study area spreads over 117,800 sq.kms. Covering major portion of urban areas some developed according to physical planning aspects whereas some developed drastically in short span, of the Bhopal district (M.P.). It refers to Survey of India Toposheet No. $55 \mathrm{E} / 8$ and bounded by latitudes $23^{\circ} 10^{\prime} \mathrm{N}$ to $23^{\circ} 15^{\prime} \mathrm{N}$ and longitudes $77^{\circ} 23^{\prime} 30^{\prime \prime} \mathrm{E}$ to $77^{\circ} 27^{\prime} \mathrm{E}$.

Bhopal-India (highlighted in Figure 3).

The watershed map of Bhopal (1990), in which different catchment were identified for analysis of water prospect map and hydrogeology wells (Figure 4) of the city for maximum recharge potential and areas experiencing sudden decline in water table. Some areas which had been showing satisfactory reactions to urbanization processes were also selected to observe the basic factor underlying their performance in natural as well as urban cycle. Also the ward map (localities demarcated as wards by Bhopal Municipal corporation at local level plan) for the

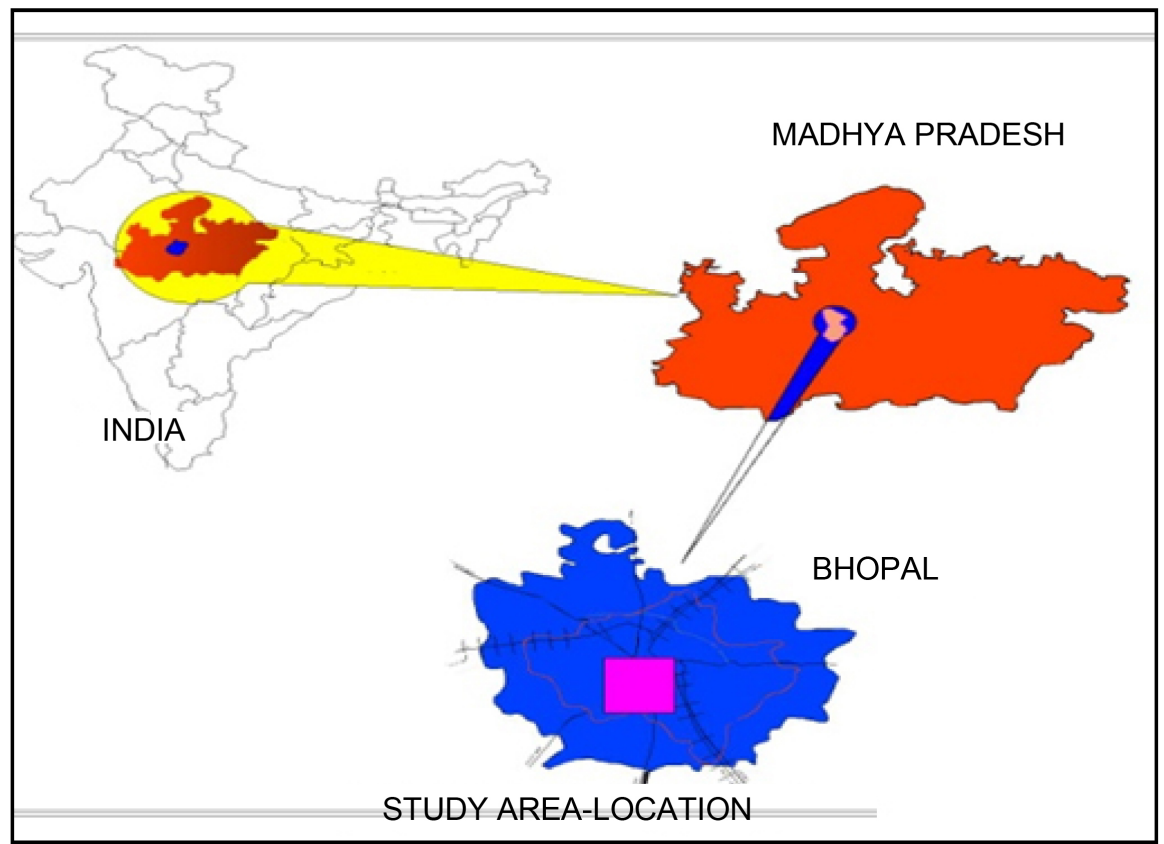

Figure 3. Bhopal city. 


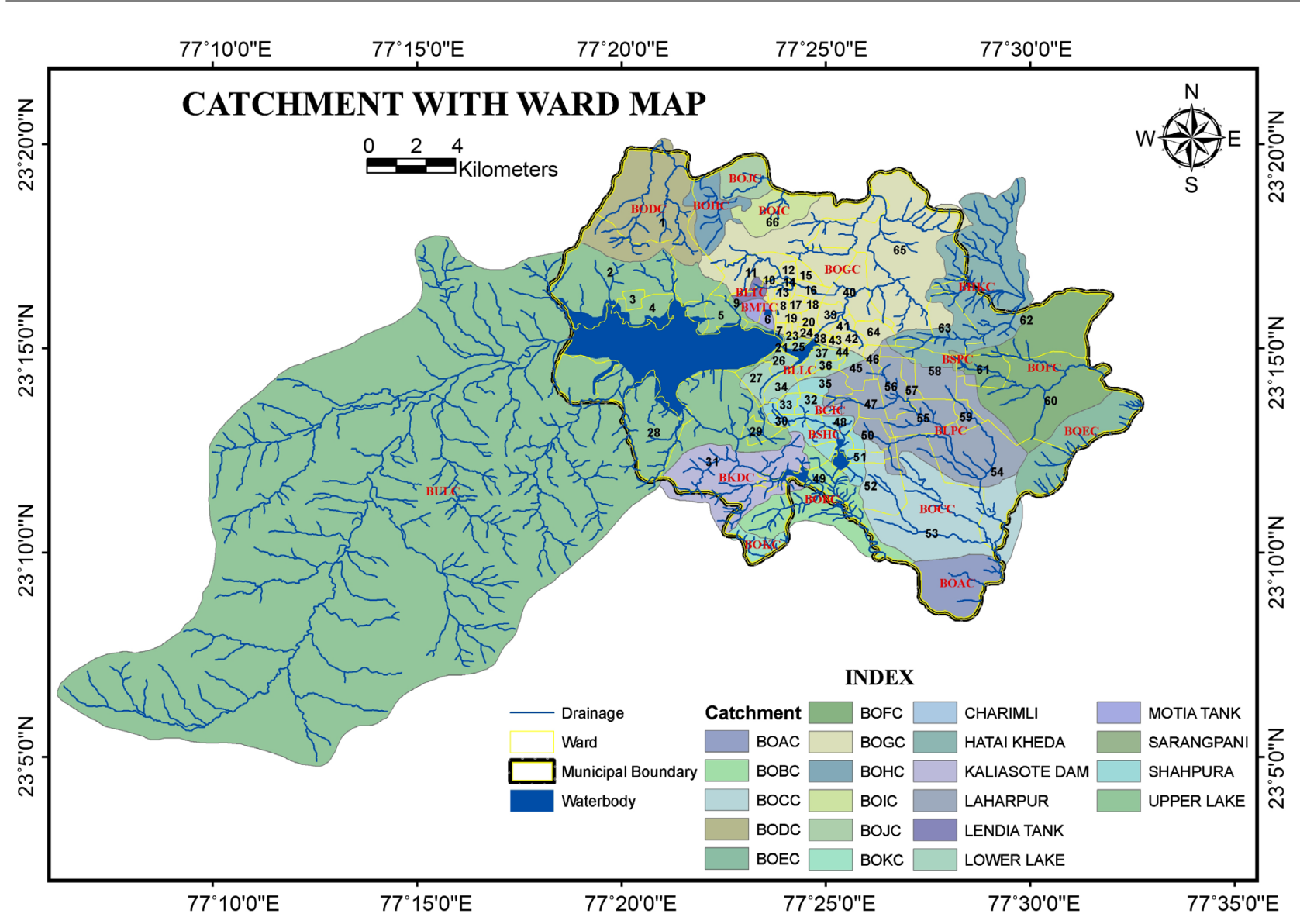

Figure 4. Catchment map for Bhopal district. Source: CGWB Bhopal [14].

same area was obtained to ascertain the areas already developed and areas still developing.

\subsection{Basic Characteristics}

Along with this CGWB report for critical water tables in city was identified [15]. As per the secondary data it was found after analysis that some areas have been critical for water table fluctuation and some had shown improvement. The areas were marked as per the hydrogeology wells location. Water prospects of the study areas which were sensitive to water development and the areas which have great natural potential or carrying capacity were highlighted such as catchments named BSHC, BOBC, BOCC (catchment names as per nomenclature use by CGWB) and catchments with poor water prospects such as BSHC (upper part), BOBC-lower part and BLPC.

- Area is underlain by Vindhyan sandstone and basalts of the Deccan Trap.

- Promising aquifer zones cited in the Vindhyan within a depth range of 60 - 70 mbgl especially at the base of Vindhyan hillocks or under a cover of weathered basalt.

- Weathered and vesicular basalts also form potential aquifers.

- Areas identified for construction of tube wells. 
- Need for rooftop rainwater harvesting stressed to make the aquifer more sustainable.

- Chemically the ground water contains high nitrate at a few places.

\subsection{Geology and Climate of Study Area}

Study areas consist of mean monthly maximum and minimum temperature as per Bairagrah observatory, to be between $44.6^{\circ} \mathrm{C}$ as maximum and $4^{\circ} \mathrm{C}$ as minimum. The table of temperature rises from March. May is the hottest month of the year and December-January are the coldest months of the year. The highest humidity level is $88 \%$ in August and lowest is $17 \%$ in April. The wind velocity is highest in June around $19.6 \mathrm{~km} / \mathrm{hr}$. and lowest is $6.8 \mathrm{~km} / \mathrm{hr}$. in November.

The average yearly rainfall has been observed as $1160 \mathrm{~cm}$. the average monthly rainfall data and its cumulative departure from average annual precipitation is tabulated in tables.

- It is observed that $93.6 \%$ of annual rainfall takes place in the months June to Sept.

$75 \%$ dependable rainfall has been worked out which is about $800 \mathrm{~mm}$.

The Geological Map obtained from the geological survey of India was observed for geology of these catchments and the different soil layers under these catchments. The hydrogeology characteristics of the area were determined. The site has been divided into different sub-catchments depending upon the Hydrogeology and the water flow pattern a shown in Figure 5.

\subsubsection{The Details of Hydrogeology and Lithology of the Area Are} Soil properties were analyzed by obtaining Geology map for Bhopal from Geological Survey of India Bhopal and study area was divided as per soil categories along with the physical and chemical properties of the soil. Table 3 shows that Deccan soil show secondary porosity where as alluvium has primary porosity assuring water holding capacity.

A grid of approximately $8 \mathrm{~m} \times 8 \mathrm{~m}$ resolution of the two selected sample areas is analyzed. The characteristics observed for the selection of the Study Area is Physiography, Geology, Drainage Pattern, Catchment Area, Rain Gauge, Planned and unplanned development and within natural environmental conditions or Altered ones and Precipitation as per CWC [16].

To Study the variations in surface flow, the observations of the catchment area and development is necessary simultaneously. The catchment area is thus defined by the boundaries and water flow within that catchment area. Thus different types and scale of catchment area are used for detail studies. Thus a micro level observation can be done with catchment of micro scale with $5-10 \mathrm{sqkm}$.

\subsubsection{Water Bearing Properties of Different Rocks in the Area}

In the Phanda Block the valleys sandstone and Deccan traps occur. Only weathered portion of basalt is eroded easily.

Most of the surveyed area is covered by Deccan traps. Some Flows of Deccan 
MAP N0.12

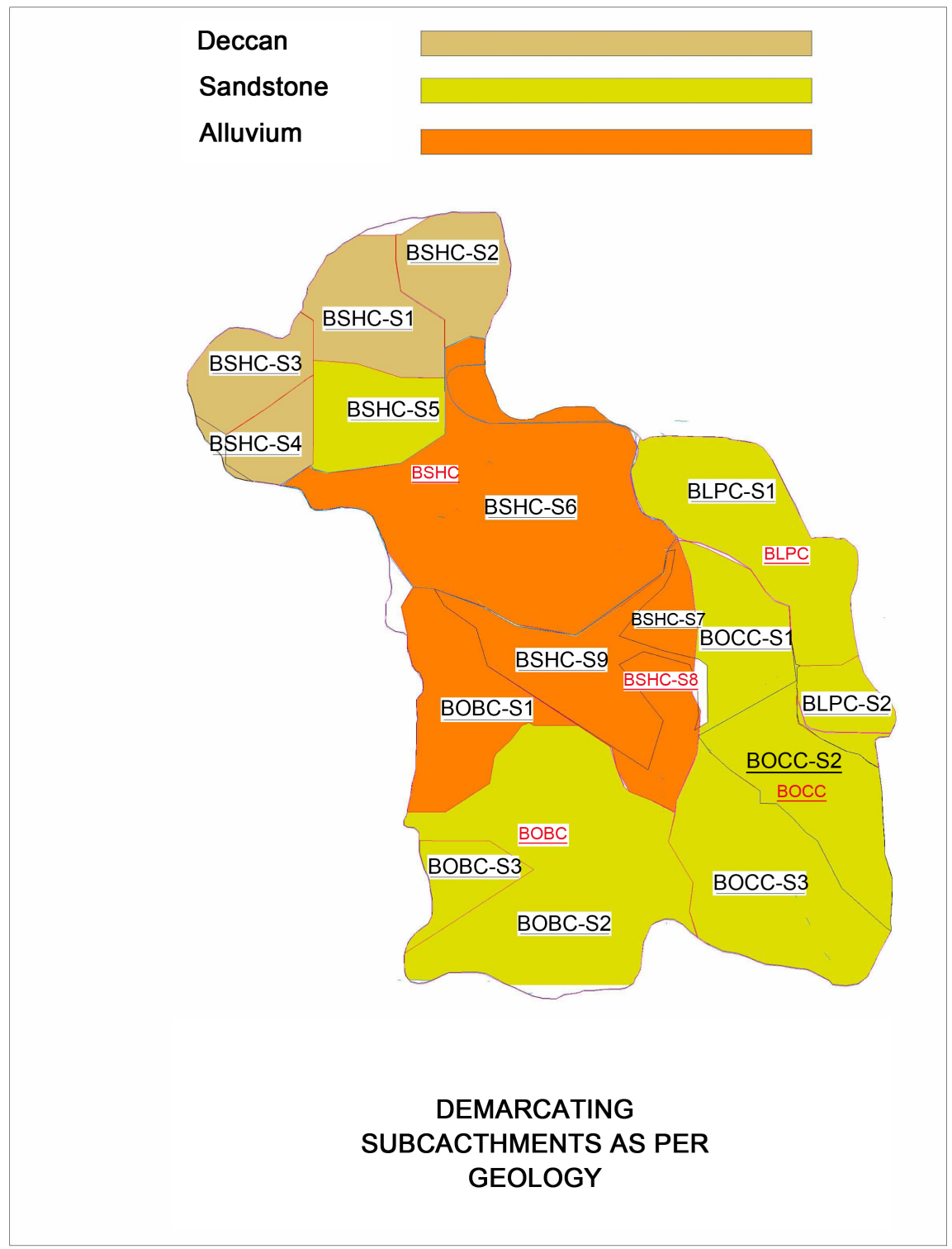

Figure 5. Sub-catchment division of study area as per geology.

Table 3. Geological characteristics of Bhopal. GSI Map of Bhopal 1986.

\begin{tabular}{cccc}
\hline SN & Age & Lithology & Ground water Potential \\
\hline 1. & $\begin{array}{c}\text { Quaternary } \\
\text { to Recent }\end{array}$ & Alluvium & $\leq 2$ Unconsolidated, Primary Porosity \\
(Areas-ChunaBhatti)
\end{tabular}


traps form Good Aquifers due to the presence of the numerous joints and presence of weathered portion along the contact of two flows, i.e., near Misrod, Bagli and Ranadia etc.

The Ground water trapped by rocks occurs both under confined and water table conditions. If well placed, the water is normally under pressure conditions.

During the rainy season the pressure are highest and during the summer seasons, they are nearly impermeable. The pressuring conditions become more pronounced in the case of a flow which occurs below one or more flows.

Where the vascular zone of the flows, along with the overlying weathered material, forms the porous zone, the water occurs under the water table conditions. The tops of some of some of the flows are vascular and fractured, which are found to hold a fair quantity of water.

The Vindhyan sandstone being well cemented acts as aquifuge, except where they are highly fractured, pointed or sheared. Black Cotton soils provide small domestic water supplies from shallow wells.

One important feature of the area is that most of the villages are situated near the banks of rivers and these rivers are responsible for recharging of aquifers.

\section{Results}

\subsection{Observations-1}

Observations for runoff and Build up in individual catchments of each soil group was done for the period of 40 years and following charts were prepared. Figures 6-11 show to variations in Build up and runoff observed in decades. The $\mathrm{x}$ axis shows Build up and Y Axis show the runoff for 1971, 1981, 1991, 2001, 2011 and 2013.

Figures 6-11 show the variation in runoff to built-up in different catchments.

Above charts 1 - 6 show that runoff increases with Build up in almost all catchments except catchments having more natural vegetation and water bodies as BSHC-S9, BSHC-S10, BSHC-S8. Apart from this, runoff observations for alluvial soil group also favor infiltration up to some extent but for less intensity rainfall and vegetated land cover like BSHC-S6, BSHC-S7, BOBC-S1, BOBC-S2, and BLPC-S1. The sandstone areas with barren land, less vegetation and Build up to

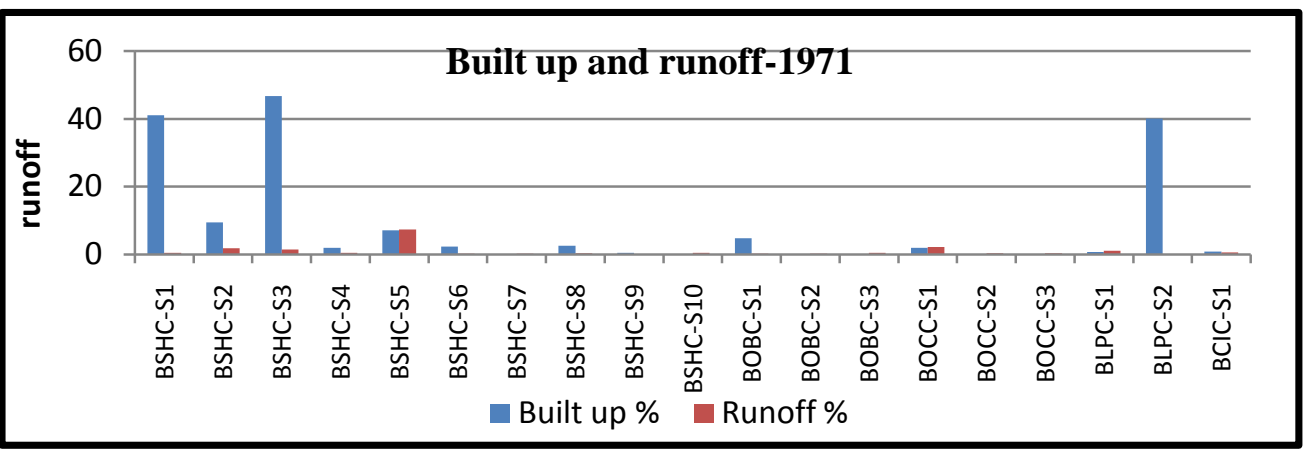

Figure 6. Build up and runoff in catchments for 1971. 


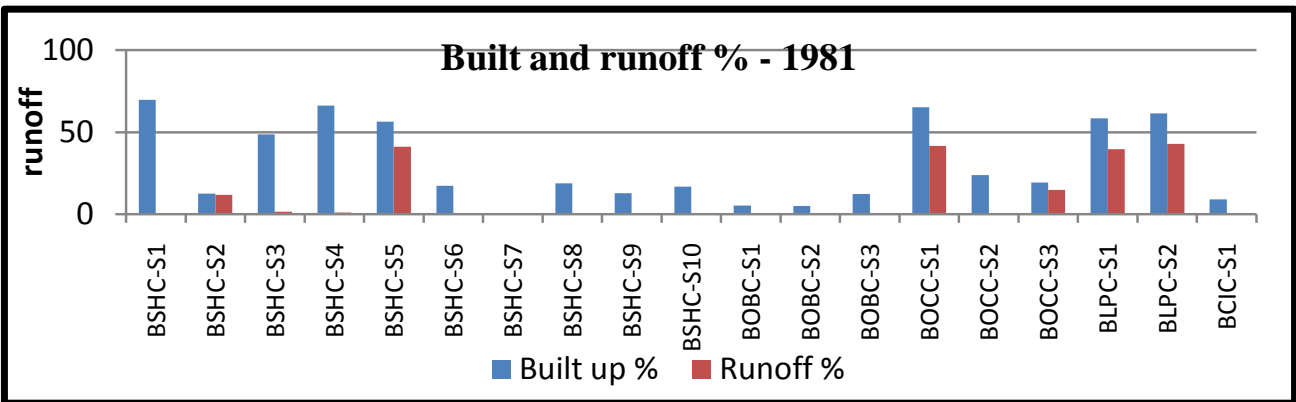

Figure 7. Build up and runoff in catchments for 1981.

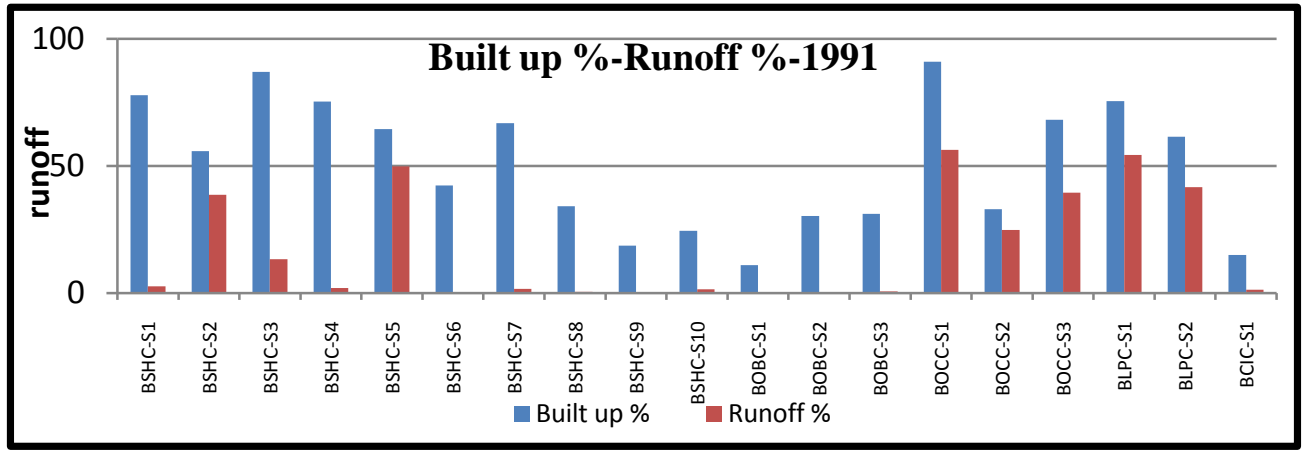

Figure 8. Build up and runoff in catchments for 1991.

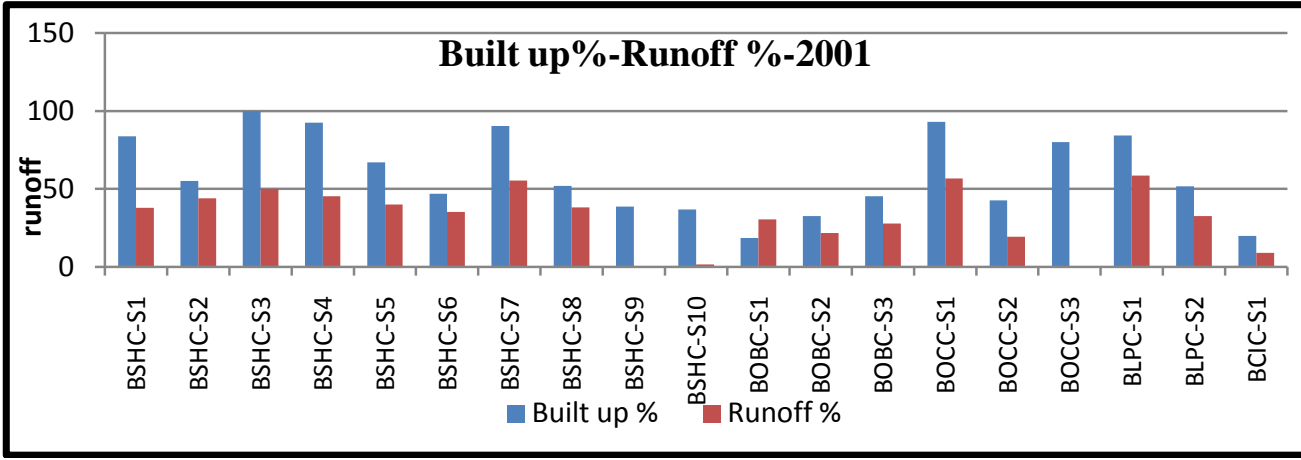

Figure 9. Build up and runoff in catchments for 2001.

50 - 60 percent have supported infiltration satisfactorily with connected impervious layers as well as combination of unconnected pervious surfaces such as BOBC-S3, BOBC-S2, and BOCC-S2 acting as recharge pits.

\subsection{Observation-2}

After observing the Build up and runoff results and their correlation with each other next stage was to correlate it with land use, land cover and catchment characteristics. Hence simulation was carried out for individual catchments for runoff, Build up and infiltration for 4 decades. The catchments were observed with behavior of hydrological cycle to urban development. Following Figures 12-18 show the selected catchments from each soil group and their variations in Build up with runoff. Coefficient of determination was also observed for trend line of 


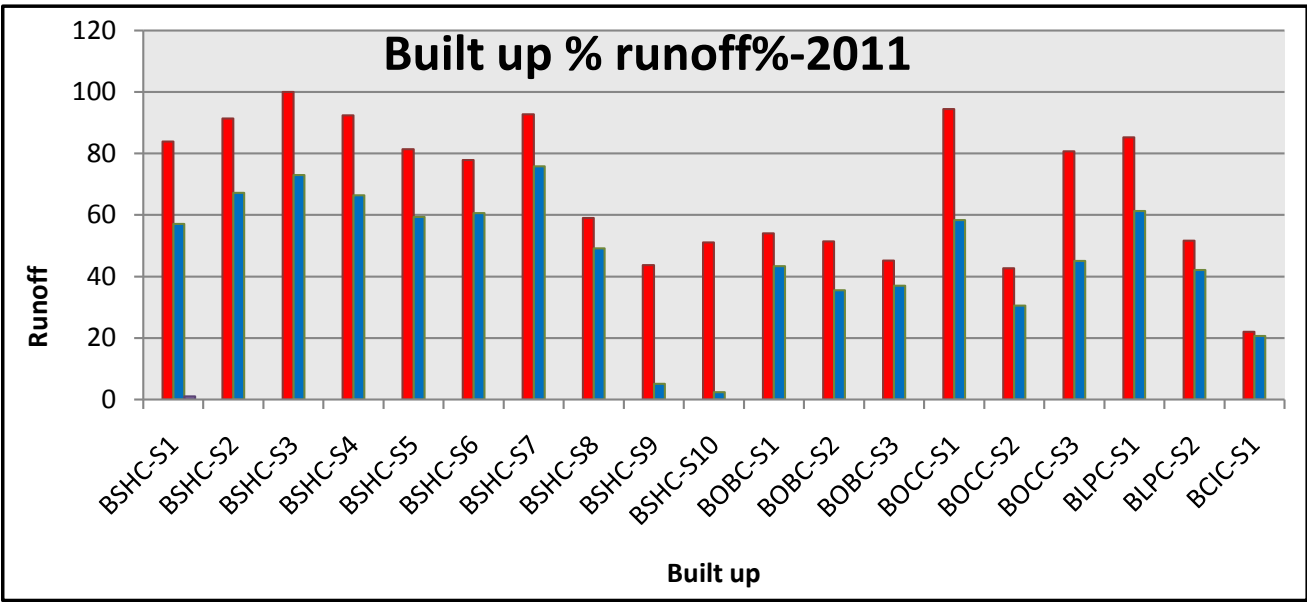

Figure 10. Build up and runoff in catchments for 2011.

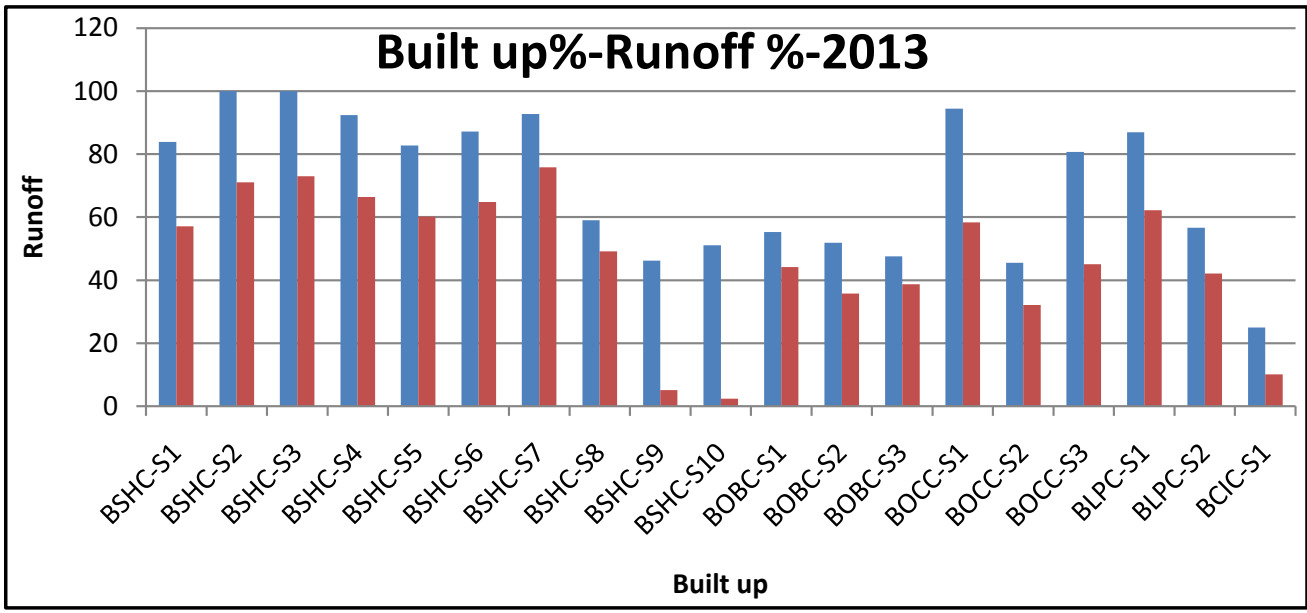

Figure 11. Build up and runoff in catchments for 2013.

catchments.

Observations for the variation in Build up and runoff for individual catchments as follows:

\subsubsection{Catchment-BSHC-S1-Sandstone}

Increase in Built-up is $42.75 \%$ and simultaneously increase in Runoff \% is $56.63 \%$. Increase in runoff is gradual till 1991-2001, but sudden increase is observed in after 1991 from $2.01 \%$ to $45.24 \%$. Though Build up has marginal increase in $0.29 \%$ at 2001 to 2011, runoff increased $20 \%$. Coefficient of determination is 0.68 and Value of $R^{2}$ is 0.874 .

\subsubsection{Catchment BOBC S1 Alluvial}

Build up has increased from $4.85 \%$ to $55.3 \%$, runoff from $0.14 \%$ to $44.15 \%$. Catchment has $60 \%$ of residential area and $60 \%$ of roads, around $37 \%$ of land cover with grass and trees. Sudden increase in runoff is noticed after 1991 where as Build up increased steeply after 2001. The blocking of natural drainages by small sized colonies developing over natural flow paths has resulted in increased runoff 


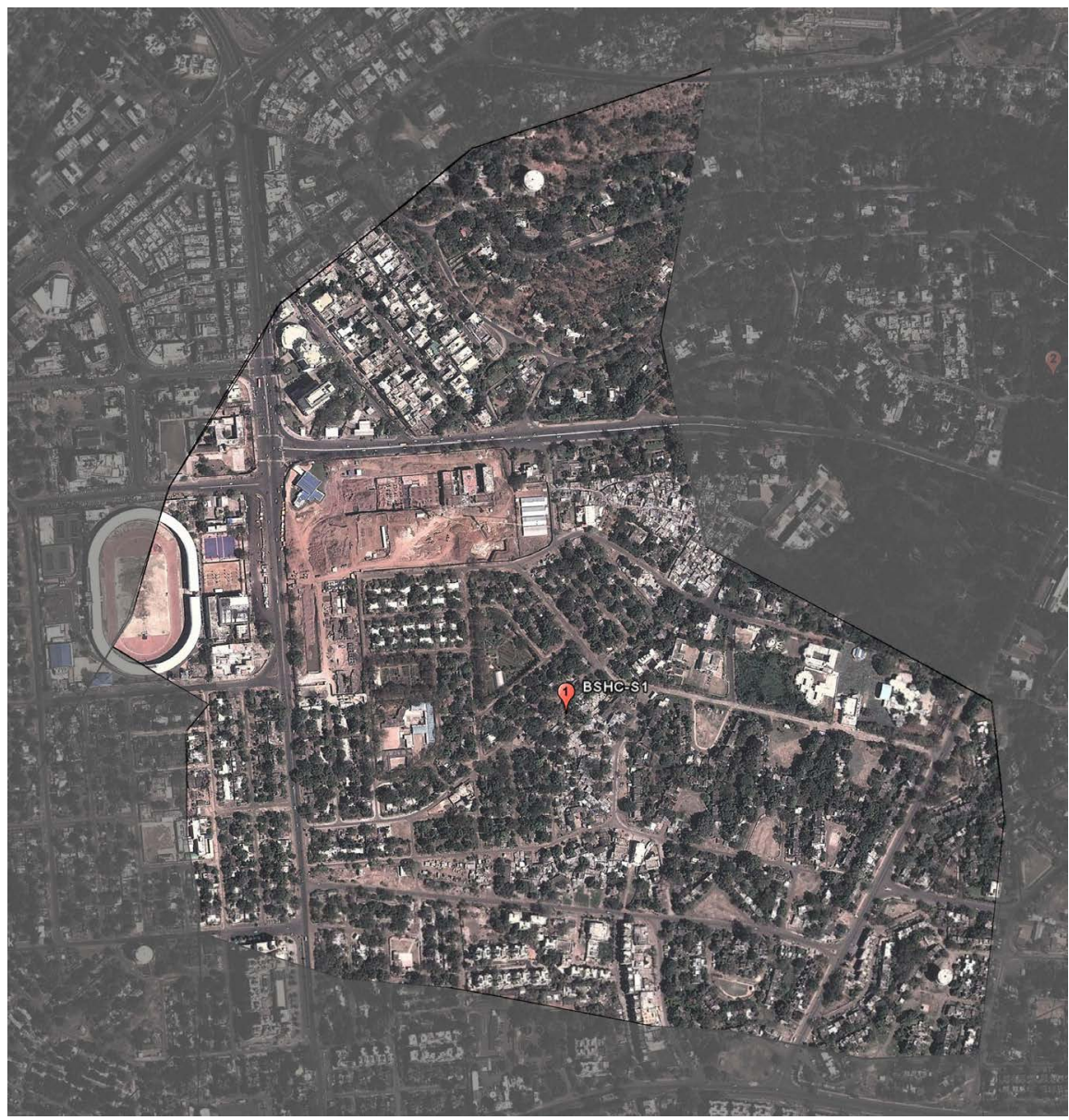

Figure 12. Build up and runoff variation in catchment BSHC-S1.

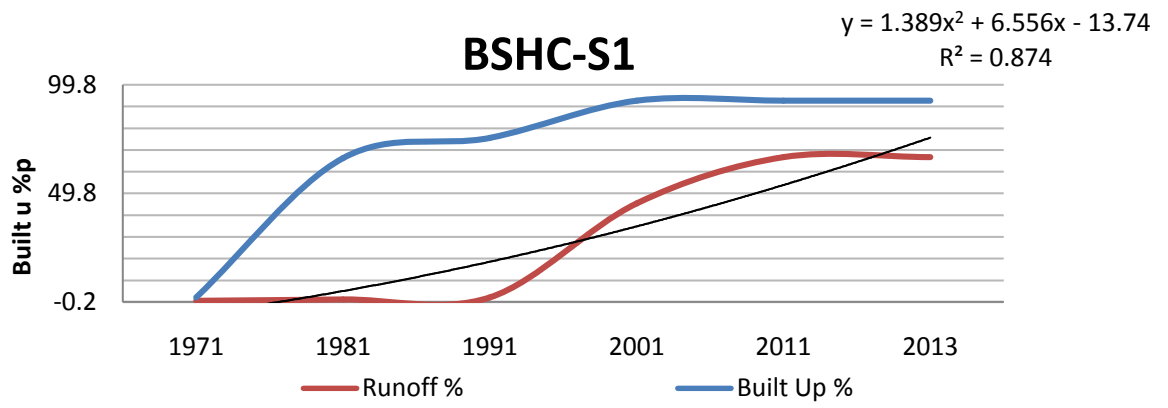

Figure 13. Build up and runoff variation in catchment BSHC-S1.

on roads and drains. The intense flow from Kaliasot dam slope increases the magnitude of runoff too folds creating a ponding in some areas and about $1 \mathrm{~m}$ flow over roads.

Coefficient of determination $=0.927, \mathrm{R}^{2}=0.868$.

\subsubsection{Catchment BSHC-S9 Basalt}

This catchment has water body around $50 \%$ of its area and experiences increase in Build up from $0.49 \%$ to $46.25 \%$ and resulting runoff from $0.0031 \%$ to $5.14 \%$. The commercial activities in and around the water body has disturbed the peak 


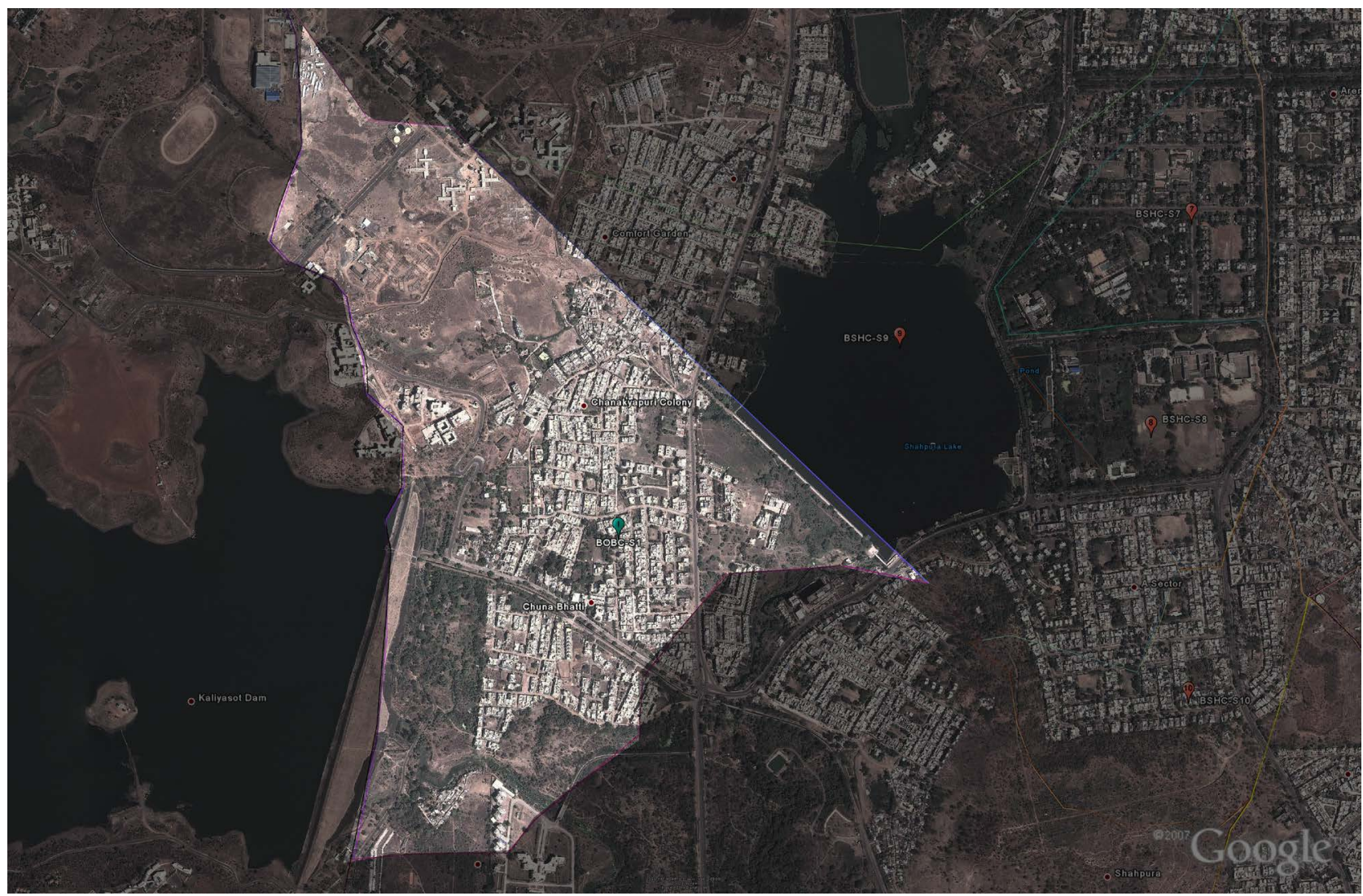

Figure 14. Build up and runoff variation in catchment BOBC-S1.

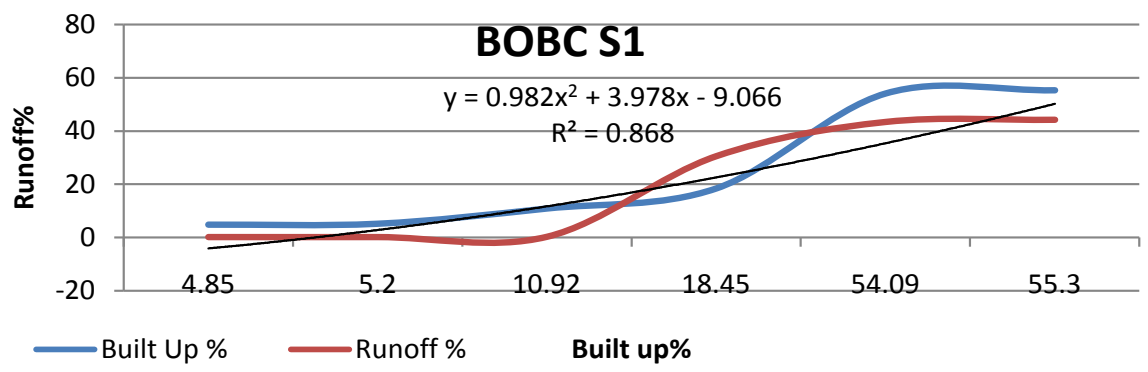

Figure 15. Build up and runoff variation in catchment BIBC-S1.

flows for this area still maintaining the general runoff very much less thus helping the recharge potential a lot. Water levels in this area show satisfactory recharge.

Coefficient of determination $=0.749$ and $\mathrm{R}^{2}=0.830$.

\subsubsection{Three Scenarios of Hydrological Behavior}

There were three scenario studied in the simulation of runoff and recharge which consisted study area in undeveloped stage, developed stage and one with actual conditions where colony development norms and building regulation were not followed by the public leading to extreme conditions. Hence simulation was carried for Ideal conditions which if followed by public would have given better results as shown in Table 4. 


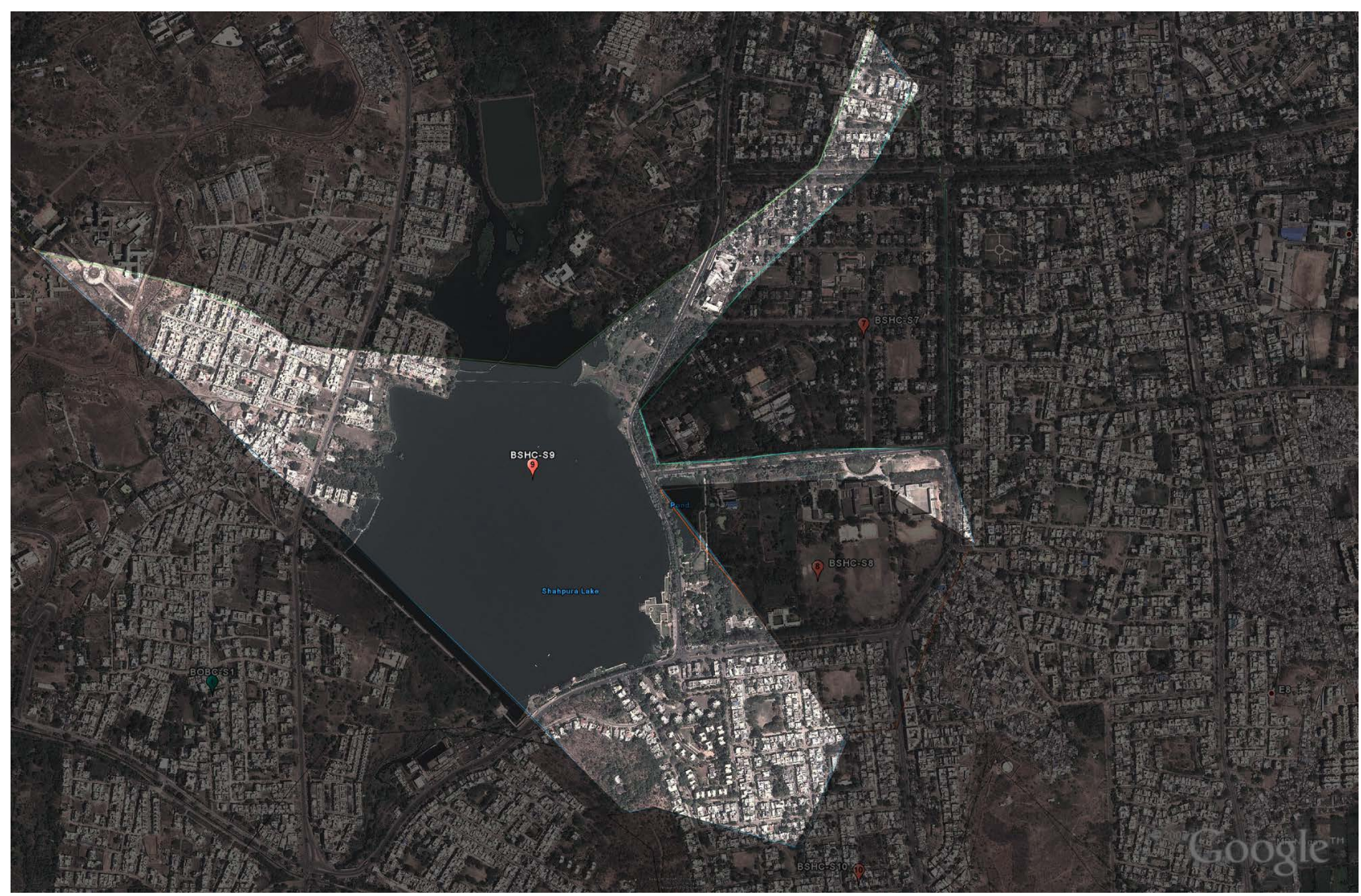

Figure 16. Build up and runoff variation in catchment BSHC-S9.

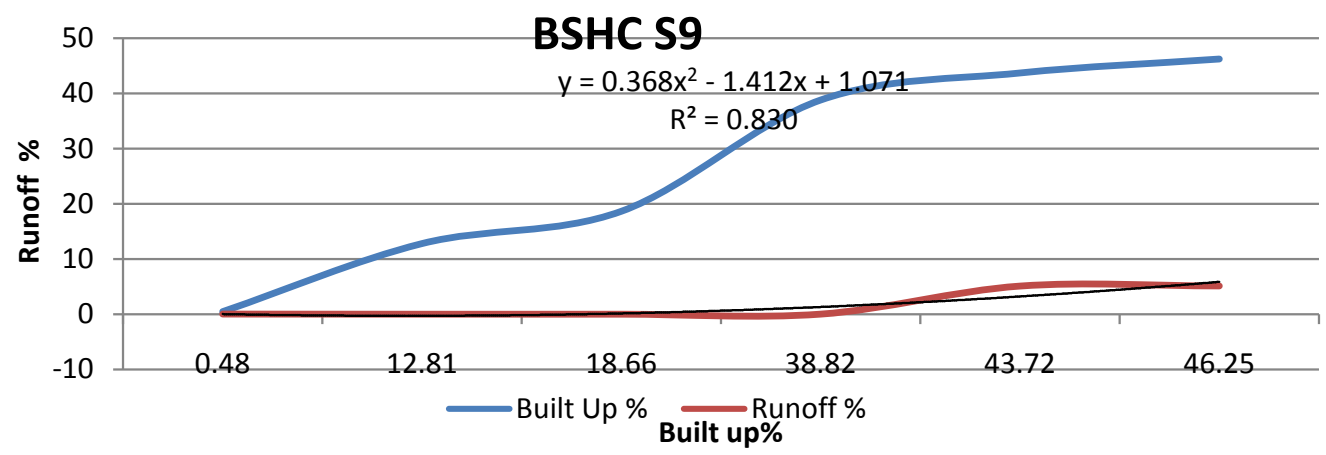

Figure 17. Build up and runoff variation in catchment BSHC-S9.

\subsubsection{Geology Based Observation for Peak Runoff}

After analyzing the effects of unplanned and uncontrolled development in study area the average favorable conditions for maintaining healthy environmental conditions were sorted out like mentioned in Table 5. Here it shows that sandstone managed to bear pressure till $83 \%$ Build up on it whereas Basalt could bear only $43 \%$ pressure. Alluvium, being best porous lacked to bear Build up for $26 \%$ only and indicating its work best with suitable land cover over it.

\section{Conclusions}

Peak runoffs in almost all catchments have shown changes out of which areas 


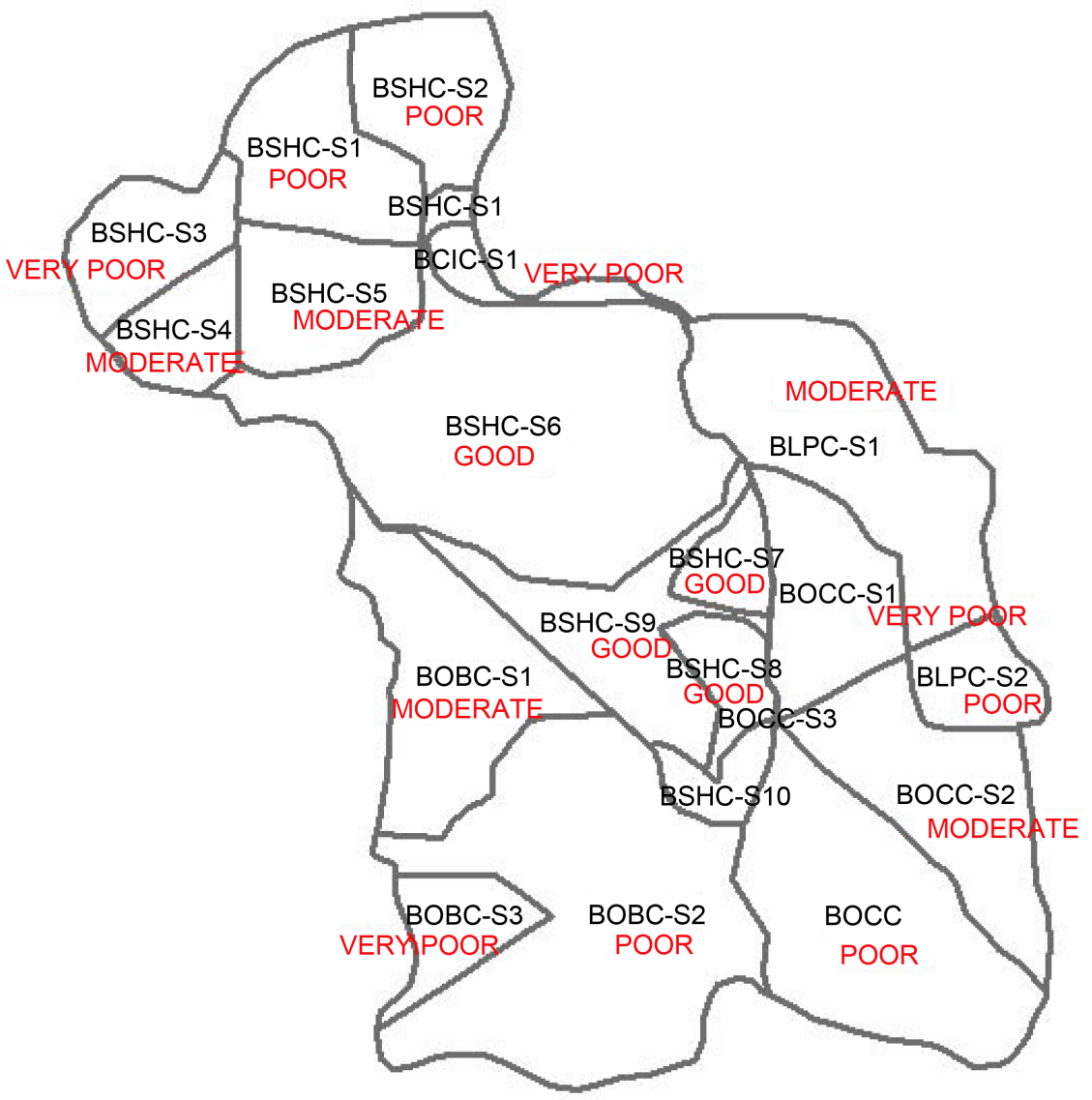

CATCHEMNTS RESPONSE TO URBANIZTION

Figure18. Areas demarcated as good and poor zone.

Table 4. Soil group and their behaviour for runoff.

\begin{tabular}{cccc}
\hline Surface flows & Actual\% runoff & $\begin{array}{c}\text { Development if as } \\
\text { per norms \% runoff }\end{array}$ & $\begin{array}{c}\text { Ideal\% } \\
\text { suggestive }\end{array}$ \\
\hline Alluvium & 87.59 & 54.69 & $20-30$ \\
Basalt & 84.65 & 49.8 & $50-60$ \\
Sandstone & 83.48 & 56.72 & $45-50$ \\
\hline
\end{tabular}

Table 5. Best correlation for soil groups and runoff.

\begin{tabular}{|c|c|c|}
\hline Sandstone $=$ & $\begin{array}{l}49 \% \text { to } 89 \% \text { less with peak runoff } \\
20 \% \text { to } 49 \% \text { less with moderate runoff }\end{array}$ & $\begin{array}{c}26 \% \text { to } 83 \% \text { build up-good } \\
\text { on sandstone }\end{array}$ \\
\hline Basalt $=$ & $\begin{array}{c}16 \% \text { to } 53 \% \text { less with moderate runoff } \\
56 \% \text { to } 90 \% \text { less with peak runoff }\end{array}$ & $\begin{array}{c}20 \%-42.5 \% \text { build up-good } \\
\text { on basalt }\end{array}$ \\
\hline Alluvial soil= & $\begin{array}{l}50 \% \text { to } 60 \% \text { less with peak runoff } \\
10 \%-20 \% \text { less with moderate runoff }\end{array}$ & $\begin{array}{c}3.4 \% \text { to } 26 \% \text { build up-good } \\
\text { on alluvial. }\end{array}$ \\
\hline
\end{tabular}

with basalt and sandstone covered with less rough areas had maximum peak discharges. Infiltration has been constantly reducing in years as evaporation and 
peak flows

\subsection{Ground Water Potential of Geology along with Development}

The excellent groundwater potentials areas in the Natural Drainage are intersection points of lineaments and valley fills marked on the map especially in Deccan Trap area, where slope is nearly level to be moderate and Build up is satisfactory for urban development and natural working. These are contributing to form aquifer zones, this is also realized by well inventory and field observation at villages ChunaBhatti and BairagarhChichli, where artesian condition of some of the wells has been noticed. The area is characterized by presence of loose and unconsolidated material. Figure 18 shows the behavior of catchments as category from good to poor.

\section{AREA A-VERY GOOD TO GOOD}

This zone is specially considered for buried pediments of Deccan Trap having gentle slope and medium Build up area. Wells observed in this unit are having less water table fluctuation. The area is characterized by Basalt with considerable depth of weathering.

(Catchment BSHC-S6, S7, S8, S9, BOCC-S3)

AREA-B GOOD TO MODERATE

This zone is found mainly in the central portion of the study area covered by weathered vesicular basalt filled with secondary fillings having gentle slope. Geomorphologically the area is marked as buried pediment, which is almost flat with little undulations and maximum cultivation.

(BSHC-S5, S4, BLPC-S1, BOCC-S2, BOBC-S1)

\section{AREA-C MODERATE TO POOR}

This zone is mainly confined to areas having moderate slopes and minor lineaments, which are playing major role to develop the semi confined conditions. Mesa tops, Vindhyan sandstones are coming under this category and water is moderately available only along lineaments. Scanty cultivation is seen over the area.

(BSHC-S2, BSHC-S1, BLPC-S2, BOCC-S3)

\section{AREA-D POOR}

Northern and Southwestern boundary of Natural Drainage is emerged as poor zone for groundwater potential. Residual hills and structural hills of Vidhyan's sandstone come under poor potential. All these hills are covered by dense forest and scanty scrubs.

(BSHC-S3, BOBC-S2, BOBC-S3, BOCC-S1)

\subsection{Conclusions}

1) Runoff is directly proportional to land cover and precipitation. The quantity of runoff is very difficult to be minimized or stopped due to the varying precipitation pattern in recent climate changes. But it can be reduced to $40 \%$ by proper physical planning. 
Table 6. Final correlation of Build up, roughness and runoff.

\begin{tabular}{cccccccc}
\hline Area & Soil & Roughness & Vegetation & Runoff & Runoff $\%$ & $\begin{array}{c}\text { Maximum } \\
\text { Build up }\end{array}$ & $\begin{array}{c}\text { Balanced Runoff } \% \\
\text { Achieved }\end{array}$ \\
\hline $\begin{array}{c}\text { Basaltic } \\
\text { Sandstone }\end{array}$ & $\begin{array}{c}\text { Sandstone } \\
\text { (Clay, Sand, Black } \\
\text { Cotton Soil) }\end{array}$ & $0.05-0.17$ & Bushy, Scanty & Slow & $45-50$ & $60 \%-80 \%$ & 20 \\
Loamy Basalt & Loamy & $0.011-0.17$ & Scanty & Medium & $55-60$ & $60 \%-70 \%$ & 30 \\
Deccan Basalt & Loamy Sand & $0.24-0.41$ & Heavy & Very Slow & $65-70$ & $30 \%-40 \%$ & 15 \\
Deccan & Silty Loam & $0.05-0.24$ & Interval & Average & $30-40$ & $15 \%-20 \%$ & 25 \\
Alluvial & Silt, Clay & $0.17-0.24$ & Moderate & Low & $10-20$ & $80 \%-90 \%$ & 35 \\
\hline
\end{tabular}

2) Balanced combination of Build up, open space, Geology and Drainage analysis can improve the flash floods and help in recharging the ground.

3) The old approach of moving surface water quickly out through drains needs to be changed as manmade drains are unsuccessful if not designed as Sustainable Urban Drainage (SUD), instead principle of "catch water where it falls" should be practiced.

4) Geological characteristics like Deccan trap, alluvial soil and sandstone plays an important role in resulting runoff and recharge depending upon the land cover provided.

5) Urban planning needs special areas to act as interception channels and storage places for surface runoff, along with provision of effective open spaces from plot level to zonal level.

6) Wise land use planning is needed for allocation of resulting land cover and clear regulation are needed for Marginal open spaces in various land uses.

7) Definition of open needs to be revised. Old rules of Ground coverage, FAR should be revised in order to achieve effective open spaces in urban areas.

8) Natural drainages need to be preserved to carry peak discharges.

9) Each parcel of land is drainage itself and hence needs alternative route to play it role when modified.

10) Larger colonies have more scope for recharge pits and open space for holding water compared to small colonies.

\section{Suggestions}

After observing the behavior of soils, Build up and land cover the best combination of all four were sorted to its best as shown in Table 6. The roughness values demonstrate the land cover in form of vegetation and bushes.

\section{References}

[1] IPCC (2007) Climate Change 2007: Impacts, Adaptation and Vulnerability: Contribution of Working Group II to the Fourth Assessment Report of the Intergovernmental Panel.

[2] Kundzewicz, Z.W., et al. (2007) Freshwater Resources and Their Management. In: 
Parry, M.L., Canziani, O.F., Palutikof, J.P., van der Linden, P.J. and Hanson, C.E., Eds., Climate Change 2007: Working Group II: Impacts, Adaptation and Vulnerability, Cambridge University Press, Cambridge, 173-210.

[3] United Nations Educational Scientific and Cultural Organization (UNESCO) (2006) Water: A Shared Responsibility. The United Nations World Water Development Report. Berghahn Books, New York, 120-156.

[4] Hengeveld, C.V. (1982) Role of Water in Ecology. Elsevier Scientific Publishing Company, Amsterdam.

https://www.researchgate.net/publication/270984881_Role_of_water_in_urban_eco $\underline{\operatorname{logy}}$

[5] Sharma, B.S. (2006) Global Climate Change due to Urbanization and Its Impact on Water Resources. Abstract, 1-8.

[6] Kazmierczak, A. and Cavan, G. (2011) Surface Water Flooding Risk to Urban Communities: Analysis of Vulnerability, Hazard and Exposure. Landscape and Urban Planning, 103, 185-197.

[7] Water, N., Inventory, Q. and US EPA (1996) 4.0 Environmental Assessment. 1-49.

[8] Xu, C. (2000) Climate Change and Hydrologic Models : A Review of Existing Gaps and Recent Research Developments. Water Resources Management, 13, 369-382.

[9] Gleick, P., et al. (2011) The World's Water Volume 7: The Biennial Report on Freshwater Resources. Global Planet Change, 7, 377.

[10] Scope, C. (1993) Chapter 4 : Management Measures for Urban Areas-D: Relationship of This Chapter to Other Chapters and to Other EPA.

[11] California Department of Water Resources (2003) Chapter 6: Basic Groundwater Concepts. DWR Bull, 118, 79-104.

[12] Agvise Laboratories Canada (2001) Educational Articles-Agvise Laboratories. http://www.Agvise.com http://www.agvise.com/educational-articles/water-holding-capacity/

[13] Sharma, S. (2015) Correlating Urban System and Hydrological System in Context of Physical Planning. International Journal of Scientific \& Engineering Research, 6, 1334-1348.

[14] Sharma, S. (2013) Statistical Change Detection in Water Cycle over Two Decades and Assessment of Impact of Urbanization. Open Journal of Modern Hydrology, Scientific Research, 165-171. https://doi.org/10.4236/ojmh.2013.34020

[15] CGWB (2014) Hopal Water Prospects. Centra Ground water Board, Bhopal.

[16] CWC and WRD (1988) Flood Estimate Report for Chambal Subzone-1(B). Hydrology (Small Catchment), Directorate, Central Water Commission, New Delhi. 
Submit or recommend next manuscript to SCIRP and we will provide best service for you:

Accepting pre-submission inquiries through Email, Facebook, LinkedIn, Twitter, etc. A wide selection of journals (inclusive of 9 subjects, more than 200 journals)

Providing 24-hour high-quality service

User-friendly online submission system

Fair and swift peer-review system

Efficient typesetting and proofreading procedure

Display of the result of downloads and visits, as well as the number of cited articles Maximum dissemination of your research work

Submit your manuscript at: http://papersubmission.scirp.org/

Or contact ojss@scirp.org 